\title{
Ação educativa em museus: a Terceira Idade construindo conhecimentos a partir de objetos no MAE/USP
}

\author{
Judith Mader Elazari*
}

\begin{abstract}
ELAZARI, J.M. Ação educativa em museus: a Terceira Idade construindo conhecimentos a partir de objetos no MAE/USP. Revista do Museu de Arqueologia e Etnologia, São Paulo, 19: 337-354, 2009.
\end{abstract}

Resumo: Este artigo trata de ações educativas em museu com público de Terceira Idade. Será apresentada a metodologia deste trabalho, que envolve a exploração de objetos de idosos e suas histórias de vida. Abrangerá também um paralelo entre duas oficinas para idosos, com metodologias de trabalho semelhantes e resultados diferenciados que tiveram como trabalho final a montagem de uma exposição com os objetos contextualizados.

\footnotetext{
Palavras-chave: Memória - Educação - Objetos biográficos - Terceira Idade - Museu
}

\section{Introdução}

1 ráticas sociais são desenvolvidas em museus e são colocadas a serviço da sociedade e de seu desenvolvimento. Partindose desta premissa constata-se que os museus não têm mais apenas a função de guardar, preservar e catalogar coleções, mas eles também investigam e comunicam, produzindo conhecimentos que contribuem tanto para a construção de memória como para uma concepção crítica da sociedade (Chagas: 2005).

O museu é um lugar de memória e como tal, esta instituição se propõe a dar espaço para que diferentes grupos sociais tenham suas histórias de vida preservadas, estudadas e compartilhadas. Esta é a forma de o museu

$\left({ }^{*}\right)$ Museu de Arqueologia e Etnologia da Universidade de São Paulo. Serviço Técnico de Musealização, Área de Educação.<judimel@usp.br> reconhecer as identidades dos povos, valorizando-as assim como as suas culturas. É o local de comunicação com a sociedade, é um espaço privilegiado de encontros e de contato com a alteridade, um lugar de "mediação cultural" (Nascimento 2007: 268).

Os bens culturais produzidos em diferentes sociedades fazem parte do Patrimônio Cultural. É um dos papéis do Museu guardar e preservar estes bens mas, como vimos, esta não é mais a base das ações museais, mas as práticas sociais. Identidade e memória vão garantir a produção e reprodução dessas práticas.

A Memória é uma imagem construída pelos materiais e representações que envolvem a sociedade ficando a sua disposição e o lembrar não é só o reviver, mas é o refazer, reconstruir, repensar, com as imagens de hoje e as experiências passadas (Bosi 1987: 17).

José do Nascimento Junior considera a memória "vinculada a nossa consciência da existência do tempo e do espaço - passado, 
presente e futuro - onde criamos identidades e referências e nos situamos no mundo; é ela que nos possibilita o exercício individual e coletivo do sentimento de pertencimento. Ao se referir à memória, está se pensando também em afetos, sensações, percepções e experiências" (Nascimento 2007: 264).

E como envolver o Museu, Patrimônio Cultural e a Memória nas práticas sociais?

Ulpiano Bezerra de Meneses pondera que é com uma formação crítica oriunda da Educação que os museus devem se comprometer ao trabalhar essas questões. Educação para este estudioso é "garantir ao indivíduo condições para que ele continue a educar-se, ou, em outras palavras, educar é promover a autonomia de seres conscientes que somos, capazes de proceder a escolhas, hierarquizar alternativas, formular e guiar-se por valores e critérios éticos, reconhecer erros e insuficiências, propor e repropor direções" (Menezes 2000: 94).

Neste texto não estamos nos referindo à Educação Formal, a que caracteriza a instituição escolar, mas à Educação não Formal, que inclui a Educação em Museus, que procura principalmente considerar e recriar a cultura dos povos envolvidos fazendo com que a bagagem cultural de cada um seja respeitada e esteja presente no decorrer do processo educativo (Garcia: 2005). Este, por sua vez, tem um sentido de mão dupla porque o educando e o educador tanto ensinam como aprendem, resignificando as identidades e, desta forma, a memória tem mais possibilidades de se colocar aberta a ações transformadoras.

Os museus apresentam diferentes culturas e recebem públicos variados para os quais desenvolvem ações educativas. O Museu de Arqueologia e Etnologia da USP (MAE/USP) atende principalmente o público escolar, formado por professores e alunos. Entretanto, se tem tentado atrair outros públicos. Um deles é o da chamada Terceira Idade (os velhos, os idosos). Esta parcela da sociedade, por sua natureza, tem sido excluída dos "elos familiares e comunitários, o que resulta em deteriorar as relações pessoais" (Aidar 2002: 54).

Há um momento em que o indivíduo maduro deixa de ser um membro ativo da sociedade, um propulsor da vida presente de seu grupo. Esta é uma perda que sofre, mas pode ainda restar-lhe uma função própria: a de lembrar, a de ser a memória da família, do grupo, da instituição, enfim, da sociedade (Bosi 1987: 23).

A memória de velhos pode ser vista como mediadora entre a nossa geração, o hoje e os testemunhos do passado. E do vínculo com o passado é que se extrai a força para a formação da identidade (Bosi 2003: 15).

As atividades especiais para o público idoso, de forma qualitativa, passaram a ser uma das práticas sociais do Serviço Técnico de Musealização do MAE/USP, a partir de ações educativas. Elas giram em torno da inclusão. Desta forma estamos agindo em direção a um novo dimensionamento das práticas museológicas.

A elaboração e execução destes tipos de ações sociais ocorrem no presente porque é um processo constante de construções e reconstruções do que vem do passado. Optou-se por trabalhar com as histórias de vida dos idosos, partindo-se da exploração da história de seus objetos. Estes são suportes de informações sobre suas vivências.

Os objetos dos idosos que serão o objeto de estudo das ações educativas são denominados por alguns estudiosos de objetos biográficos. Violetta Morin os descreve como sendo aqueles que envelhecem com seus possuidores, são os que se incorporam às suas vidas. Eles representam experiências vividas, são insubstituíveis. Dão a sensação de continuidade e ganham maior relevância por proporcionarem o sentimento de pertencimento a uma comunidade. São eles objetos da Memória (Morin 1971: 189-195).

Os objetos biográficos podem ser considerados como construções do mundo material sobre os quais são projetadas experiências de vida de seus possuidores. Eles abrigam memórias e representações ao se evidenciarem como fontes de descobertas e, ao "contarem" a história de seus donos, são expressões e instrumentos de memória (Almeida: 2007).

Além de serem biográficos os próprios objetos têm a sua biografia e esta tarefa de 
registrar os diferentes níveis biográficos é, segundo José Nascimento Junior, uma das funções dos museus ao musealizar e contar as histórias dos objetos e de seus donos (Nascimento 2007: 104). ${ }^{1}$

\section{Atividades Educativas com o público da Terceira Idade no MAE/USP}

As primeiras atividades educativas com o público da Terceira Idade realizadas no MAE/ USP se deram em 1989, no antigo MAE, ${ }^{2}$ quando foram atendidos idosos da Faculdade de Saúde Pública da USP. Foram trabalhadas questões relativas à memória individual e coletiva, relacionadas às experiências vividas por cada um, problematizadas as questões sobre a preservação das minorias. Houve por parte dos participantes uma reação viva de identificação quando tiveram contato com objetos arqueológicos.

Entre 1994 e 1996 desenvolvemos o Projeto "Patrimônio Cultural e Memória: a Terceira Idade no MAE/USP". ${ }^{3}$ Foram atendi-

(1) As atividades educativas que serão aqui relatadas se dão num museu universitário de Arqueologia e Etnologia o que permite estabelecer uma analogia, a grosso modo, entre os objetos biográficos dos idosos e os objetos arqueológicos. Ambos são suportes de informações; a partir deles podem ser descobertos conhecimentos até então guardados/conservados na memória dos idosos ou sob camadas de terra; a eles são feitas questões e levantadas hipóteses, respondidas ou não. Alguns dos conhecimentos obtidos a partir deles podem ser modificados quando houver novos achados ou novas interpretações e questionamentos. E ainda, as descrições, análises e interpretações desses objetos estão sendo feitas no presente "que contém o produto de atividades dinâmicas realizadas no passado" (Neves 1995: 173). Eles permitem a obtenção de conhecimentos sobre os povos/pessoas aos quais pertenciam tais objetos, sobre sua produção, seu valor simbólico, seu valor social etc. E não ficam distantes desta interpretação os objetos biográficos.

(2) O atual Museu de Arqueologia e Etnologia da Universidade de São Paulo foi criado em 1989 com a fusão de acervos arqueológicos e etnográficos do antigo MAE, do Museu Paulista, do Instituto de Pré-História e do

Departamento de Antropologia da Faculdade de Filosofia , Letras e Ciências Humanas (acervo Plinio Ayrosa).

(3) Tendo em vista a falta de experiência com atividades educativas dirigidas ao público da Terceira Idade no MAE/ dos cerca de dez grupos já organizados (pelo SESI, Igreja Católica, Prefeitura de São Paulo etc.), nas suas próprias sedes, atingindo-se cerca de 240 pessoas.

Nesta proposta desenvolveu-se uma troca de idéias sobre Arqueologia, Museu e Patrimônio Cultural, conhecimentos nem sempre problematizados anteriormente por estes grupos. Ao final, foi organizada uma mostra de objetos pessoais dos integrantes do grupo, os quais eram contextualizados e mostrados para os demais componentes dos outros grupos. ${ }^{4}$

Outra forma de trabalho, realizada entre 1997 e 2004, consistiu de visitas orientadas à exposição de longa duração "Formas de Humanidade", na sede do MAE/USP vinculadas às atividades do Programa "Universidade Aberta à Terceira Idade”, da Pró-Reitoria de Cultura e Extensão Universitária da USP (PRCEU/USP). Eram visitas mensais, oferecidas ao público idoso espontâneo, mas tiveram pouca procura.

Finalmente, desde 2005, vem sendo desenvolvido um projeto contínuo e sistemático, em forma de oficina, com a duração de um semestre e reuniões semanais de duas horas. Este Projeto chamou-se inicialmente Oficina da Memória: A Terceira Idade Construindo Conhecimentos no MAE/USP. Algumas pessoas o procuraram porque pensavam que seria uma oficina para melhorar a memória e quando constatavam que não seria para isso, desistiam da Oficina. Por esta razão, desde 2008 ele se intitula Arqueologia e Memória: Oficina para a Terceira Idade.

As principais premissas que norteiam essas Oficinas são as seguintes:

- Museu como agente educacional, tendo em vista ações educativas que

USP, buscou-se conhecer outros Projetos realizados com este público, em museus: no Museu de Arte Contemporânea da USP, onde o educador Silvio Coutinho desenvolve até hoje o Projeto Envelhecer com Arte e no Museu Lasar Segall, o Projeto Retratos de Imigrantes, de 1990, realizado por Denise Grinspum, Marcelo Araujo e Marília Xavier Cury. (4) Para conhecer mais detalhes deste Projeto vide: Elazari (1997). 
possibilitem tanto considerar como reavivar a cultura de pessoas nela envolvidas, fazendo com que a bagagem cultural de cada um seja compreendida e respeitada.

- Sociabilidade, prazer, ludicidade e aprendizagem: estas são atitudes, sensações e sentimentos que auxiliam na valorização da auto-estima dos indivíduos.

- Reconstrução da memória do passado no presente a partir de objetos, levando a histórias de vida dos envolvidos.

- Paralelo entre os conhecimentos sobre homens do passado, obtidos a partir das pesquisas arqueológicas e o trabalho com memória de velhos como construção de conhecimentos sobre homens e mulheres da sociedade atual.

- Memória, Identidade e Museus: relacionados a ações educativas que propiciam o sentimento de pertencimento ao grupo de onde provêm, possibilitando que grupos geralmente excluídos deixem de se sentirem marginalizados e possam passar a ter o sentimento de pertencimento.

- Socialização de histórias de vida a partir de objetos com os quais são montadas exposições pelos próprios envolvidos, dando-se oportunidade ao público em geral de se envolver e aprender com tais vivências .

Essas premissas estão relacionadas à metodologia e aos fundamentos educacionais que são desenvolvidos, em ações educativas com diferentes públicos, no Serviço Técnico de Musealização do MAE/USP.

O trabalho educativo, baseado nas premissas acima, foi desenvolvido em etapas visando à contextualização teórica e etapas com atividades práticas, que são sempre inter-relacionados, como se observa a seguir:

Etapas para a contextualização teórica do processo de trabalho:

1. Manuseio/sensibilização e contextualização, dentro de uma visão crítica, de objetos arqueo- lógicos e etnográficos desenvolvendo habilidades intelectuais, tais como: observação, análise, classificação, crítica, relações, comparações, levantamento de hipóteses etc. ${ }^{5}$

2. Leitura de textos e troca de idéias sobre conceitos utilizados durante todo processo do trabalho educativo, tais como: Arqueologia, Memória, Museu, Cultura Material, Patrimônio Cultural e outros.

3. Contato com algumas etapas do trabalho arqueológico e museográfico, através de visita aos "bastidores" do MAE: visita aos Serviços de Curadoria; de Biblioteca e Documentação e de Musealização.

4. Visita orientada e à exposição de longa duração "Formas de Humanidade" ${ }^{6}$

5. Noções específicas de Expografia, possibilitando o conhecimento básico sobre montagem de exposições museográficas.

6. Observação e análise crítica de exposições de outras instituições museológicas.

\section{Etapas com atividades práticas:}

1. Simulação de escavação arqueológica, realizada em caixas de areia, onde são enterrados alguns objetos para serem escavados pelos idosos.

2. "Escavação" da Memória dos idosos em busca de objetos pessoais e sua contextualização através das histórias de vida dos velhos.

3. Registro oral, escrito e figurativo das histórias de vida relacionadas aos objetos, (desenhos de objetos dos próprios idosos, dos colegas, das exposições visitadas etc.) e fotográfico (realizado pela coordenação dos grupos e por fotógrafo profissional).

(5) Os objetos manuseados nesta etapa do Projeto são os seguintes: ponta de projétil, raspador e furador lascados; lâmina de machado e afiador; fragmentos cerâmicos; cestos e peneiras de fibra vegetal e lamparina greco-romana, de argila. (6) A exposição de longa duração Formas de Humanidade se divide em três setores. Setor I: Brasil Indígena (Módulos: Origens e Expansão das Sociedades Indígenas e Manifestações Socioculturais Indígenas), Setor II: África: Culturas e Sociedades e Setor III: Mediterrâneo e Médio Oriente na Antiguidade (Módulos: Pré-História Européia, Egito, Mesopotâmia, Grécia e Roma). 
4. Planejamento e elaboração de projeto de exposição com os objetos e outras linguagens de apoio (síntese do processo de trabalho).

5. Montagem e abertura da exposição para o público em geral.

6. Avaliação do processo de trabalho educativo.

7. Possíveis desdobramentos das Oficinas, após a desmontagem da exposição (exs: montagem de outra exposição, livreto explicativo etc.).

\section{Estudo de casos: duas oficinas com
metodologia de trabalho semelhante \\ Estudo de casos: duas oficinas com
metodologia de trabalho semelhante e resultados diferenciados}

Será apresentado a seguir um paralelo entre ações educativas desenvolvidas por dois grupos de idosos de origens diferentes, com os quais foi aplicada uma metodologia semelhante, mas cujos resultados foram diferenciados.

Primeira oficina: Encontros com Idosos: "Escavando" a Memória a partir de Objetos. ${ }^{7}$ Este projeto foi realizado pelo MAE/USP em parceria com o Centro de Saúde Escola do Butantã (ligado à Faculdade de Medicina da USP). Os idosos já se reuniam com a educadora de saúde e agentes comunitárias de saúde do Centro de Saúde, na Comunidade São Remo. Esta se localiza a cerca de 200 metros do MAE, vizinha da Cidade Universitária da USP, separada por um muro, não somente de concreto! Este grupo se encontrava desde 2005 para

(7) Projeto Encontros com idosos; "Escavando" a Memória a partir de objetos - Participantes do grupo: Epifanio Fernandes, Francisca Tenório, Givalgina A. Borges, Isabel X. dos Reis, João H. da Silva, José A. da Silva, Palmira de Oliveira e Raimundo J. Irineu; Educadora de Saúde: Beatriz Pereira; Educadora de Museu: Judith Mader Elazari; Agentes Comunitárias de Saúde: Rita de Cassia Silva e Gislene de Almeida; Estagiária (Bolsa Trabalho- COSEAS/USP): Karina Giusti - (grupo da São Remo). discutir e refletir sobre questões de saúde, tendo como principal objetivo melhorar a qualidade de vida dos participantes através da valorização dos mesmos.

Constou da programação cultural deste grupo, uma visita ao MAE/USP. Fizeram-na justamente no dia da inauguração da exposição "Memória e Vivências", montada por outros idosos de uma Oficina da Terceira Idade. Após este primeiro contato, foram feitas algumas reuniões conjuntas entre a educadora do MAE/USP e o grupo, surgindo a idéia de se realizar um projeto, sendo parceiras duas unidades da USP tão diversas, mas trabalhando juntas a partir do trabalho educativo desenvolvido por ambas (Foto $\mathrm{A}$ ). ${ }^{8}$

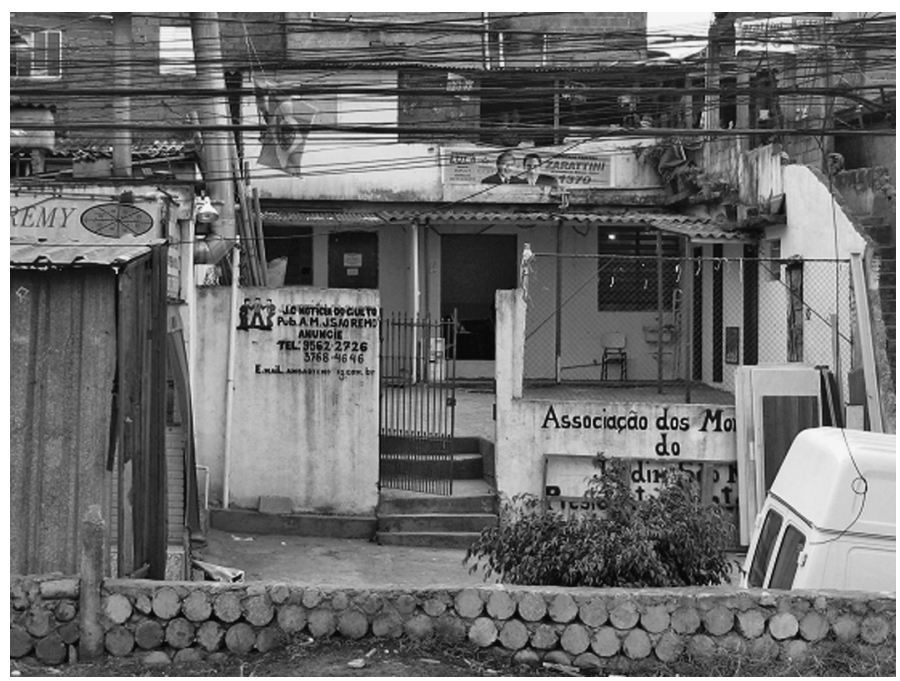

Foto A. Fachada da Associação de Moradores da Comunidade São Remo.
Segunda Oficina: Oficina da Memória: A Terceira Idade Construindo o Conhecimento no MAE/USP: este grupo se formou espontaneamente, após a divulgação feita pela PRCEU/ USP, dentro de seu Programa Universidade Aberta para a Terceira Idade. ${ }^{9}$

(8) Créditos das fotos deste artigo: Wagner Souza e Silva, Karina Giusti, Cida Santos e Judith Mader Elazari - Acervo fotográfico do Serviço Técnico de Musealização do MAE/USP).

(9) Projeto Oficina da Memória: A Terceira Idade construindo o conhecimento no MAE/USP - Participantes do grupo: Aparecida do Amaral, Dora Dias, Eleny V. Gomes, Eleonora A. Cardoso, Ellen P. Schaffa, Enyr C. Veiga, Elisa 
As reuniões de ambos os grupos se deram basicamente no primeiro semestre de 2006, semanalmente, com duração de duas horas, sendo que as do primeiro grupo se realizaram na Associação de Moradores da Comunidade São Remo e as da outra Oficina, na sala de Atividades Educativas do MAEUSP.

1. Características dos integrantes dos grupos:

Escolaridade: todos os componentes da São Remo eram analfabetos ou semi-analfabetos (assinavam o nome) enquanto os da Oficina da Memória tinham no mínimo o nível fundamental e alguns o nível universitário.

Procedência geográfica: os da São Remos vieram de alguns estados do Nordeste brasileiro, chegando a São Paulo na idade adulta e os da Oficina da Memória eram da cidade de São Paulo, do interior do estado ou de outros países (Alemanha e Líbano).

Infância: devido às vivências de cada um, os da São Remo só tinham lembranças tristes e algumas senhoras pediram para não relatá-las porque não gostam de lembrar de tanta tristeza, enquanto que os da Oficina da Memória consideram esta fase da vida bastante positiva e fizeram questão de recordá-la e alguns idosos disseram que esta foi a fase da vida mais feliz de suas vidas.

Envelhecimento: sabemos que cada sociedade e mesmo dentro delas, há formas diferenciadas de se encarar o declínio biológico do homem da mulher e neste item os dois grupos também se diferenciaram bastante: o da São Remo encarou a velhice como um descanso e recolhimento merecido depois de tanto tempo de trabalho duro e desgastante. Todos estão aposentados ou recebem pensão alimentícia. Para os da Oficina da Memória este período era de alegria, liberdade e de novos conhecimentos, não uma ruptura com o trabalho árduo e obrigatório.

G. Broitman, Fares Youssef Murr, Kazuê Y. F. Santos, Luciana de A. Stanize, Maria Elisa V. Krauze, Maria Menegheni dos Santos, Ninon H. Moussalli, Thereza M. J. Arantes, Vanda Incao, Verenice L. Ribeiro, Yedda D. Rebouças e Zulmira G. Leite; Educadora de museu: Judith Mader Elazari; Estagiária: Karina Giusti - (grupo da Oficina)
Saúde física: todos os integrantes do grupo da São Remos tinham algum problema de saúde, uma vez que foram contatados no Centro de Saúde. Tiveram que trabalhar prematuramente (alguns com três ou quatro anos de idade), trabalho duro e pesado, má alimentação, insalubridade. Os da Oficina da Memória não precisaram trabalhar na infância, não executaram trabalhos braçais pesados e algumas mulheres somente foram donas de casa.

Lazer: os idosos da São Remo tinham como lazer a TV, atividades nas suas respectivas Igrejas e visita a parentes, enquanto os da Oficina tinham o hábito de ir ao cinema e teatro, viajar pelo Brasil e fora dele, participar de atividades especiais para a Terceira Idade etc.

Situação econômica: este item não foi aprofundado, mas era muito visível a discrepância econômica entre os dois grupos.

Sentimento de pertencimento e comprometimento com o grupo de trabalho, assim como a assiduidade dos integrantes (estes itens estão relacionados): o grupo da São Remo demorou mais para se envolver no trabalho, houve muitas ausências, principalmente das mulheres que por quaisquer motivos não compareciam (visita em casa, doença, frio etc.). Já o outro grupo estava desde o início envolvido com o trabalho e cada vez mais integrado.

Os objetivos gerais destas oficinas foram os seguintes:

1. Tornar mais rica a vida dos integrantes da Terceira Idade.

2. Propiciar aos idosos a oportunidade de ter uma relação prazerosa com os novos conhecimentos construídos e adquiridos no decorrer do trabalho educativo.

3. Incentivar os velhos a refletirem sobre seu papel na sociedade, tanto no passado como hoje.

4. Refletir sobre a memória individual e sua relação com a coletiva na medida em que forem reconstruídas e compartilhadas pelo grupo. 
5. Desenvolver através de ação educativa e do trabalho com a memória relações do cotidiano de cada um com o sentimento de pertencimento e de identidade.

6. Compreender que a instituição museológica é um lugar de memória, onde se procura dar espaço a diferentes grupos sociais.

7. Promover a troca de experiência entre os velhos de modo que possibilite a sua valorização como seres produtores e consumidores de Cultura.

8. Possibilitar aos participantes dos grupos que re-signifiquem o passado por eles abandonado ou deixado de lado na sociedade em que vivem.

9. Discutir questões relacionadas à saúde, não apenas físicas, mas que também possam desenvolver a valorização do ser humano na sua totalidade.

10. Socializar com o público em geral, em forma de exposição, os conhecimentos construídos a partir de objetos biográficos.

11. Conhecer, e dar a conhecer, a história da Comunidade São Remo a partir da Memória de alguns de seus habitantes mais antigos e socializá-la entre os seus moradores.

Os primeiros nove objetivos são comuns aos dois grupos e os dois últimos são específicos para o grupo da São Remo

No decorrer do processo de trabalho foram observadas diferentes reações dos participantes dos dois grupos em relação aos mesmos objetivos e etapas de seu desenvolvimento:

1. O amadurecimento teórico sobre os diversos conceitos que permearam o trabalho teve ritmo bem diferenciado. O grupo da Oficina da Memória já trazia experiências com discussões teóricas, mesmo que nem todas de forma aprofundada. O grupo da São Remo, pouco hábito tinha de discutir qualquer tema em grupo, iniciando esta prática no Centro de Saúde há pouco tempo, mas tinha muita vergonha de se expor.
Existiram também dificuldades com relação ao vocabulário utilizado pela coordenação do grupo. Na São Remo, por exemplo, houve problema com a palavra exposição. Foram mencionadas várias vezes "visitas a exposições" e "montagem de exposição" de objetos. Percebeu-se, com o passar do tempo, que as pessoas não se colocavam, nada questionavam sobre estes assuntos e assim foi perguntado como eles achavam que seria uma exposição e disseram que não tinham idéia sobre isso. Foi, então, levada uma coleção de objetos e de fotos relacionadas a eles e montou-se uma pequena exposição. Só assim começaram a ter idéia do significado de uma exposição. A visita ao MAE/USP ampliou esta compreensão.

2. Visita à exposição de longa duração "Formas de Humanidade" do MAE/USP: pressupõe-se que um visitante quando se coloca diante de uma exposição já dispõe de uma bagagem prévia de conhecimentos e é a partir destes que irá interpretar, compreender, desfrutar e sentir a nova experiência (Asensio: s/d). O grupo da Oficina da Memória passou por toda exposição, pouco se deteve diante das vitrinas questionando o que era apresentado. Não se criou espaço para pensamento crítico, criativo ou de identidade, somente para as possibilidades cognitivas que a exposição oferece.

Entretanto, a visita à mesma exposição, realizada pela São Remo levou a reações muito especiais. Logo que chegaram os participantes foram apontando e falando sobre os objetos que haviam manuseado no início dos encontros e demonstraram contentamento por vê-los novamente e em maior quantidade (Fotos B, C, D).

Seus rostos se iluminaram quando viram objetos conhecidos, que os remetiam a vivências passadas. Trocaram idéias entre si quanto à confecção de vasilhas de argila, confeccionadas com a técnica de roletes e com as quais estavam familiarizados porque as confeccionaram em sua terra natal, juntamente com os familiares, tanto para uso como para vender. E a admiração foi grande também porque desde que moravam em São Paulo, nunca mais tinham visto esses tipos de objetos. 

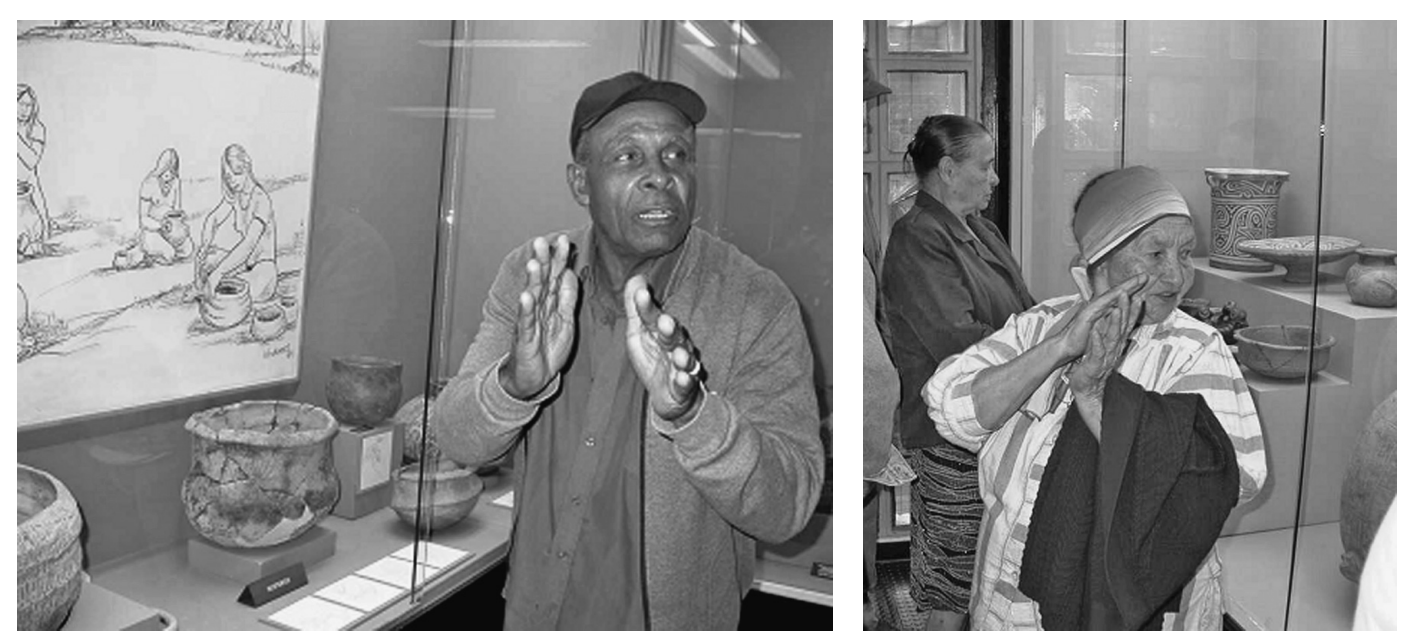

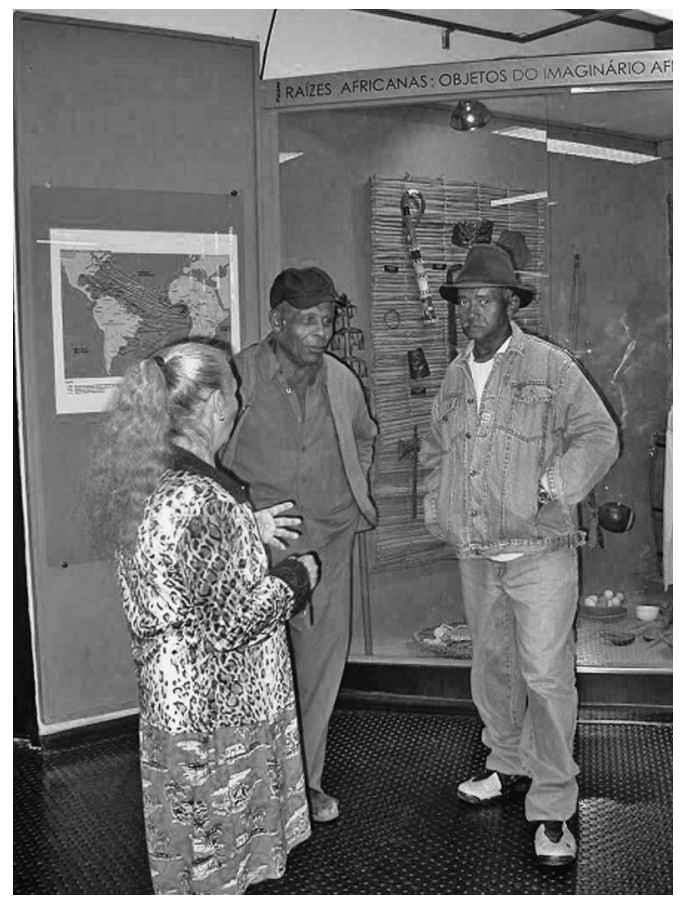

Discutiram entre si sobre o processamento da mandioca, as diferenças regionais e o trabalho que executavam com seus parentes nas plantações e moinhos de farinha, alguns trabalhando desde os três ou quatro anos de idade o que nunca mais haviam realizado.

Falaram sobre a pesca, ao verem anzóis e alguns "causos" sobre a pesca foram contados espontaneamente.

Ficou clara a memória coletiva, a partir das lembranças individuais, principalmente
Fotos B, C, D. Visita à exposição Formas de Humanidade - Grupo da Comunidade São Remo.

relacionadas a trabalho e sobrevivência, em seus espaços de origem.

Os idosos se tornaram os mediadores na exposição e os coordenadores o seu público! Realizaram um re-encontro com fases de suas vidas, esquecidas, mas reativadas a partir de objetos tão familiares, sem agora o seu valor de uso, mas que possibilitaram a reconstrução de muitos conhecimentos e a troca entre eles.

3. Encontro dos grupos que estavam desenvolvendo projetos semelhantes: tendo em vista que as duas Oficinas estavam acontecendo no mesmo período, tentou-se realizar encontros dos grupos a fim de se desenvolver atividades conjuntas. Houve, porém, um estranhamento muito grande entre eles nos poucos encontros realizados. Seriam necessárias muitas atividades especiais para a socialização das pessoas, mas como não constava dos objetivos e das etapas de trabalho, deixou-se de tentar aprofundar os encontros.

4. Escolha de objetos biográficos: a escolha de objetos em suas casas foi parte fundamental dessas oficinas. Quando foi solicitado ao grupo da São Remo que "escavasse" a memória em busca de objetos, todos disseram que não tinham nada para levar. No encontro seguinte somente duas pessoas apresentaram seus objetos e contaram suas histórias, que muito interessaram a todos. No encontro seguinte, 
todos levaram um, dois ou três objetos cada e falaram sobre eles, introduzindo-os em diferentes fases de suas histórias de vida, deixando todos muito interessados e atentos, surgindo muitas perguntas e mesmo acréscimos pessoais às histórias dos companheiros (Fotos E, F).

Os objetos ${ }^{10}$ eram utensílios domésticos ou de trabalho, houve poucos fora destas linhas. Somente três (colcha, navalha e chapéu) vieram do Nordeste, os outros foram adquiridos ou ganhos já em São Paulo.

O grupo da Oficina não se contentou em levar três objetos cada um, como era a proposta. Disseram logo no início que seria muito difícil escolher e quase não precisariam "escavar" a memória, pois os objetos "aflorariam à superfície".

Constatou-se que não era a realidade, pois, ao apresentarem os objetos, alguns disseram que procuraram muito por eles. E a escolha de um levou à lembrança de outro e algumas pessoas chegaram a ir à casa de parentes buscarem objetos que consideraram importantes em suas vidas e que até então não se haviam dado conta dessa importância. Foram
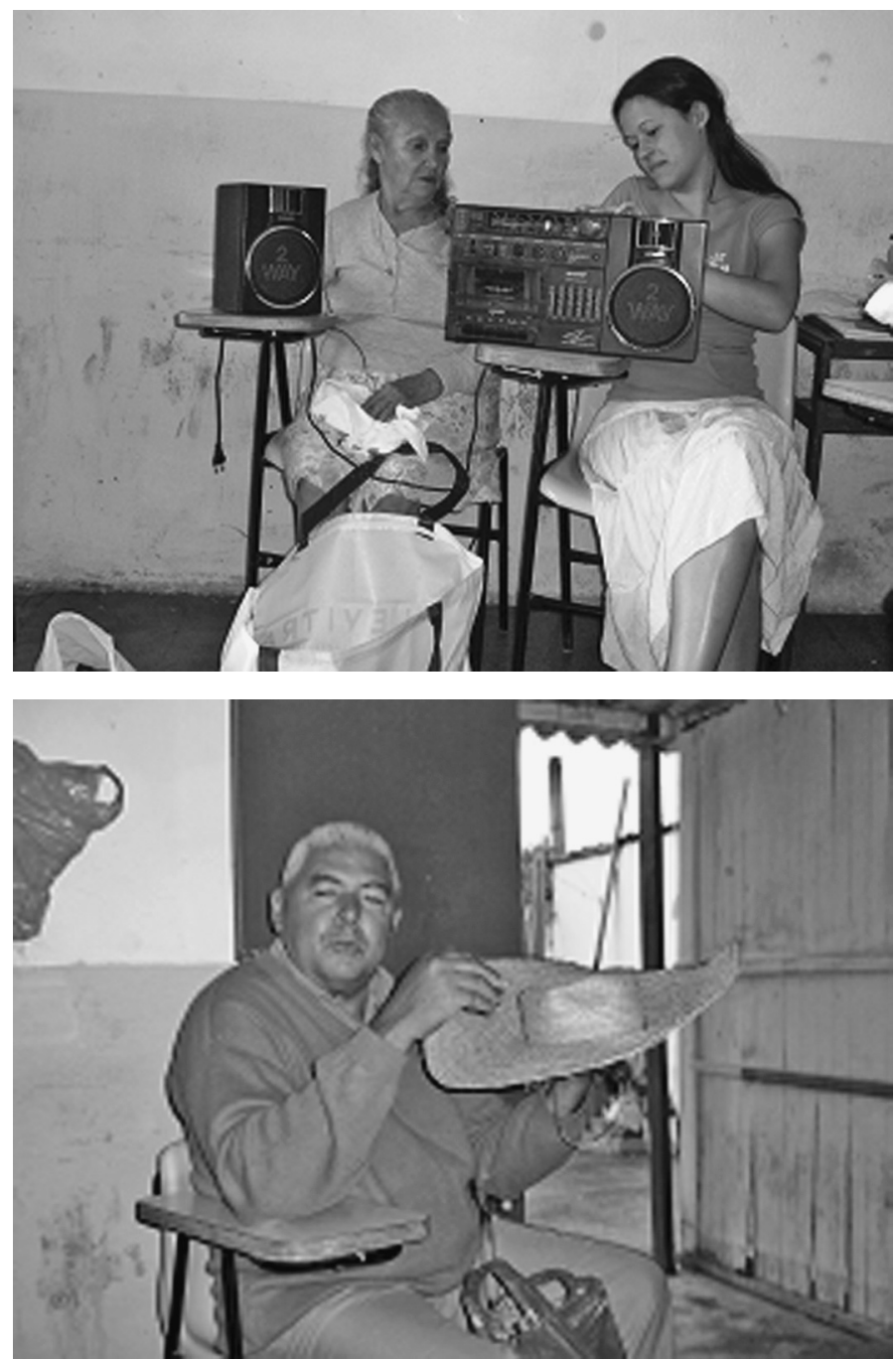

Fotos E, F. Objetos biográficos - Grupo da Comunidade São Remo.

momentos de relatarem histórias da vida familiar que estavam esquecidas, talvez por estarem estes objetos dispersos (Fotos $\mathrm{G}, \mathrm{H}$ ).

Os objetos do grupo da Oficina ${ }^{11}$ se relacionavam a lembranças de viagens, relíquias

(10) Os objetos escolhidos por este grupo foram os seguintes: canivete, navalha, pedras - escorredor de macarrão, panela de pressão, caneca de louça, tigelinha de louça, colcha de cama - chapéu, martelo, prumo - rádio. Nem todos levaram três objetos como tinha sido pedido. (11) Os objetos escolhidos por este grupo foram os seguintes: fivela de cabelo, bolsa de prata, adorno de cabeça, colar de sementes, anel, dois leques, bolsa de

de família, lembranças de infância, símbolos religiosos, presentes de pessoas significativas em

tecido, dedal, camafeu, estojo de maquiagem, par de sapatos, broche, terço de louça, chaveiro de cruz, dois livros de orações, duas bonecas, cachorro de pelúcia, camisa de pagão para batizado, macacão de criança, tesoura, lapiseira e caneta, medalha do Quarto Centenário de São Paulo, pedra ágata, quadro de flores, escultura de mulher com galinhas, ânfora de alabastro, três porta-jóias, dois álbuns de fotos, prendedor de papéis, toalhinha de "frivoletté", flor de vidro, taças, xícara de café, taça de "Baccarat", ferro de passar roupas, dois paliteiros, prato de cerâmica, porta-ovos, estojo de injeção. 

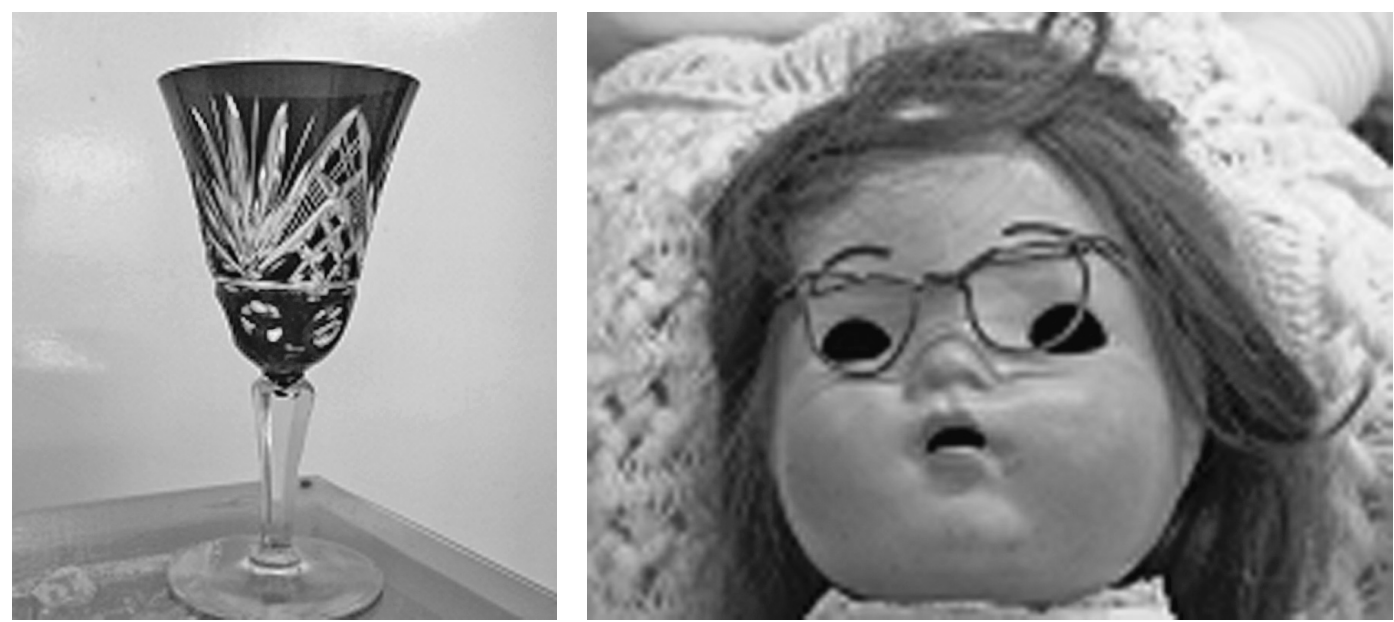

Fotos G, H. Objetos biográficos - Grupo da Oficina da Memória.

suas vidas, quase nenhum era especialmente ligado ao trabalho ou utensílio doméstico.

5. Registro dos objetos: em ambos os grupos foi feito registro fotográfico. $\mathrm{O}$ registro escrito foi realizado de forma diferenciada, pois os componentes do grupo da São Remo eram analfabetos e os coordenadores do grupo anotavam o que eles iam contando, mas alguns detalhes foram perdidos, já os da Oficina foram contextualizados em um Cadastro de Objeto. ${ }^{12}$

grupo da Oficina fez representações de alguns de seus objetos e de objetos dos colegas através de desenho, que se tornaram registros gráficos bastante significativos. ${ }^{13}$

6. Processo de elaboração, montagem e a inauguração da exposição de objetos: o grupo

(12) Do Cadastro do Objeto deveria constar: Nome do objeto; Nome do proprietário; Origem do objeto; Tempo; Contextualização/história do objeto.

(13) A avaliação deste Projeto se orientou, entre outras coisas, pelo fato de não ter sido feita, paralelamente, uma oficina de pintura e/ou desenho para estes idosos, dandolhes a oportunidade de aprender e exercitar uma atividade que nunca antes tinham tido. Considera-se válida a crítica, mas a justificativa é que no desenrolar do Projeto não houve nem tempo e nem profissionais para orientarem tal oficina. Fica porém um alerta para trabalhos futuros, em que se poderá incluir este tipo de orientação para públicos sem experiências em desenho e/ou pintura. da Oficina iniciou-o com visitas orientadas a outras exposições e com palestra sobre Noções preliminares de museografia. ${ }^{14}$ Estabeleceram os temas da exposição e das vitrinas e escolheram democraticamente o nome para ela: Escavando a nossa Memória, depois da apresentação de vários outros nomes (Fotos I, J).

Desta exposição constaram objetos dos membros do grupo, com etiquetas que continham frases explicativas, retiradas dos Cadastros de Objetos; painel fotográfico com as várias fases do processo de trabalho; painel com os desenhos dos objetos expostos, texto sobre a exposição e ficha técnica.

O público foi convidado para a inauguração e para conhecer a exposição através de convites e cartazes, mala direta e telefone. ${ }^{15}$ (Foto K)

$\mathrm{Na}$ inauguração da exposição os idosos com alguns de seus objetos fizeram uma representação para o público ${ }^{16}$.(Fotos L, M)

(14) A palestra Noções preliminares de Museografia foi ministrada pelo museólogo Mauricio Candido da Silva. (15) Os convites e cartazes para a divulgação das aberturas das exposições foram criados e elaborados pela designer gráfica do MAE Cida Santos e a divulgação das mesmas, por mala direta e telefone, foi realizada pela secretária do STM/MAE Maria Aparecida Gomes de Andrade.

(16) Estes exercícios corporais com objetos foram realizados sob a coordenação do mestrando em Artes Cênicas da ECA/USP Alexandre Calado que acompanhou o grupo em horário posterior ao da Oficina. Escolheram um de seus objetos pessoais e com eles fizeram uma apresentação 

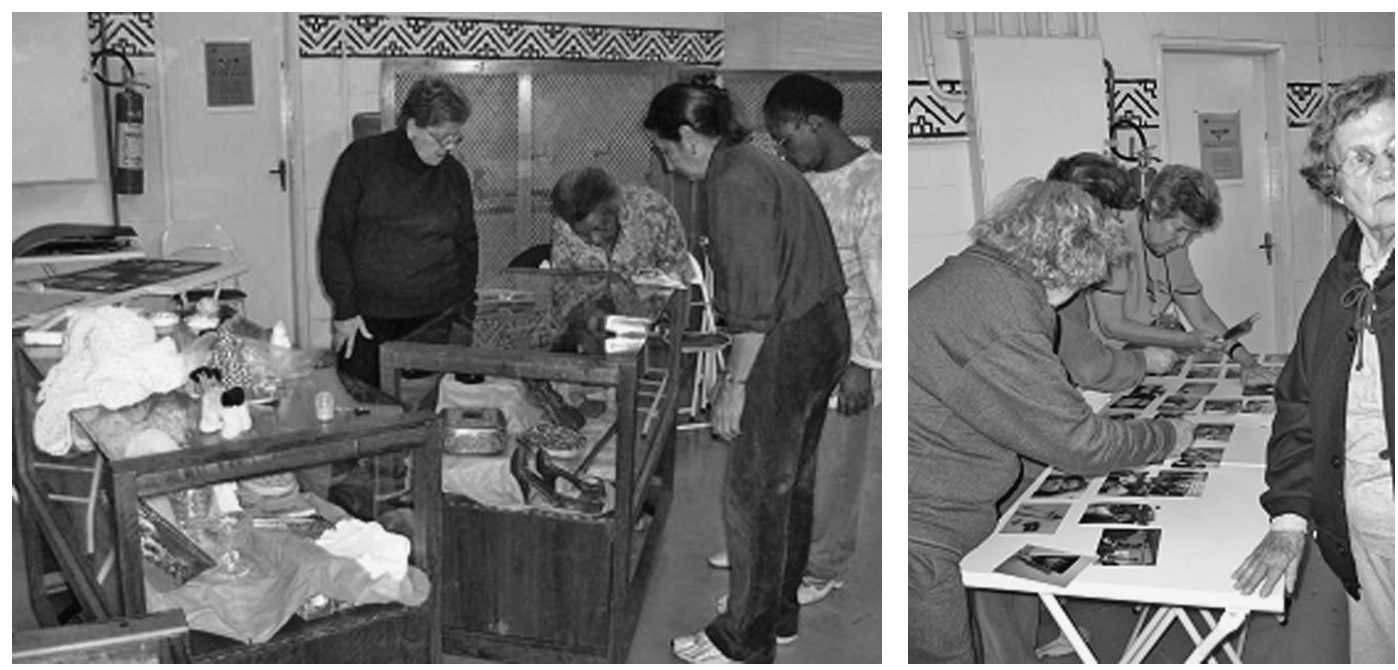

Fotos I, J. Montagem da exposição Escavando a nossa Memória.

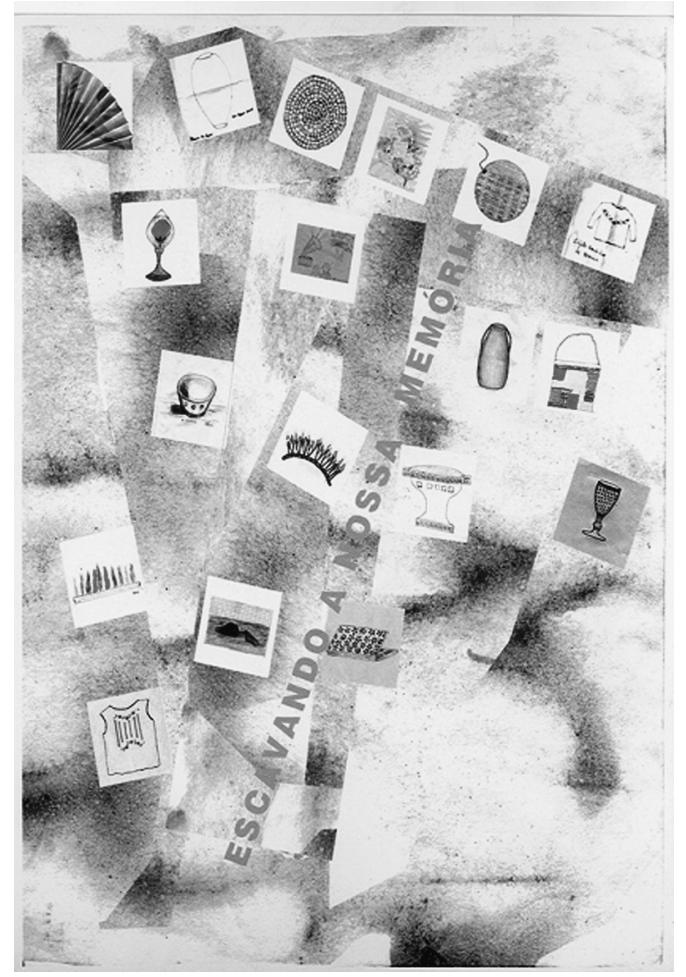

Foto K. Convite/Cartaz da exposição Escavando a nossa Memória.

dos mesmos, mas com um gestual próprio, uma representação que foi além da contextualização dos mesmos através da memória. Destes exercícios se originou um curto espetáculo que foi apresentado durante a abertura da exposição Escavando a nossa Memória.
Durante cinco dias a exposição Escavando a nossa Memória permaneceu aberta e os participantes se organizaram para ficarem de plantão atendendo aos possíveis visitantes.

A exposição de objetos dos idosos da São Remo foi planejada e montada pelos coordenadores da Oficina, com a cooperação da designer Cida Santos e do fotógrafo Wagner Souza e Silva, sem a participação dos integrantes do grupo. O nome Objetos e Lembranças não foi escolhido por eles, que somente viram a exposição no dia da inauguração. Por que? Teria sido uma atitude paternalista dos coordenadores, da qual não tiveram consciência no momento? A avaliação posterior deu conta desta atitude contraditória, alertando para que em futuros trabalhos seja evitada, permitindo que os participantes dos grupos sempre possam montar suas próprias exposições. Para isso eles necessitam estar instrumentalizados suficientemente, como estavam os integrantes do grupo da Oficina.

Essa exposição não tinha vitrinas e os objetos ficaram expostos sobre suportes, sem proteção. Foi escolhido pelo fotógrafo do MAE um objeto de cada participante os quais foram fotografados e as fotos foram ampliadas e transformadas em posters que fizeram parte da exposição. Também foi elaborado um painel com fotos sobre todo o processo de trabalho, texto explicativo e ficha técnica (Fotos $\mathrm{N}, \mathrm{O}$ ). 

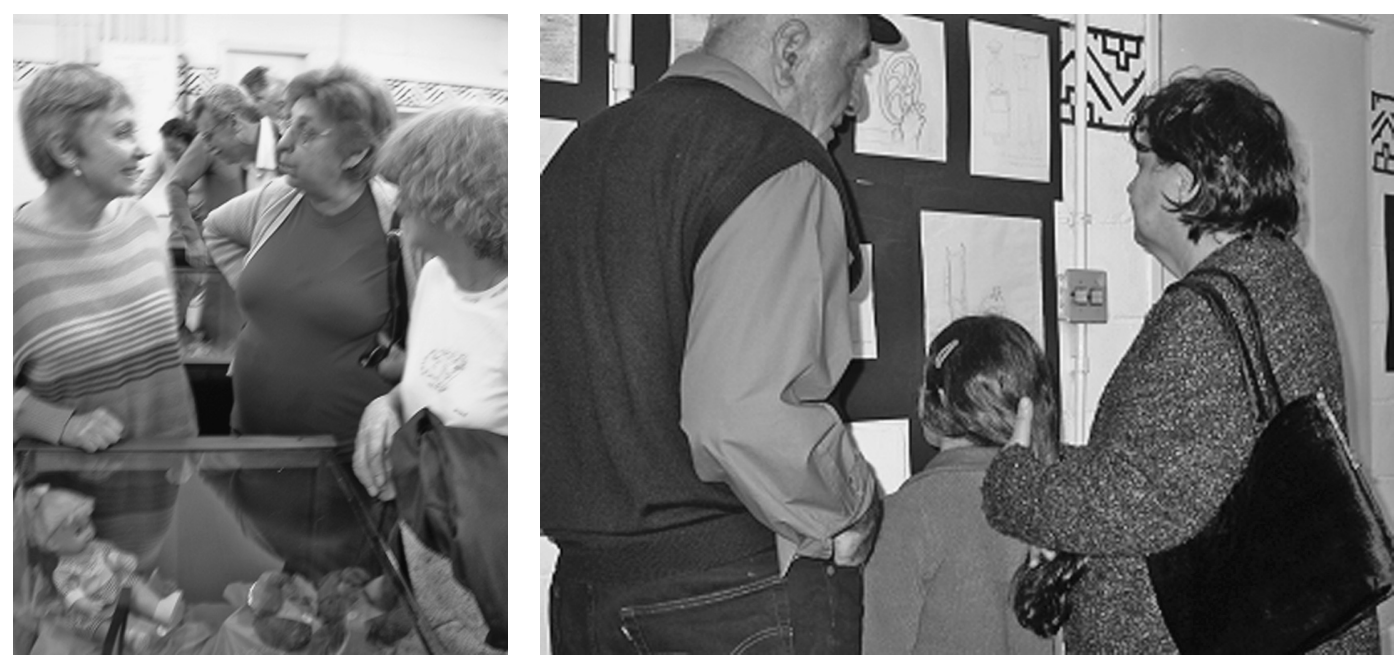

Fotos L, M. Inauguração da exposição Escavando a nossa Memória.
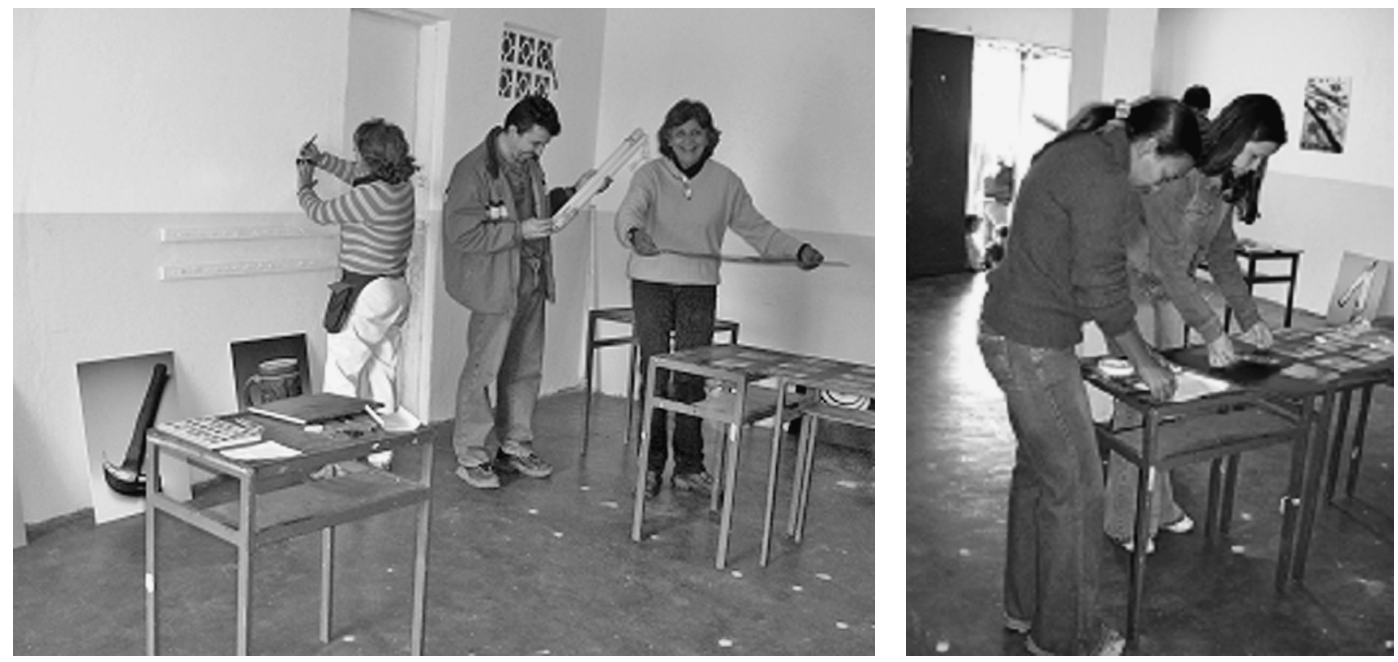

Fotos N, O. Montagem da exposição Objetos e Lembranças.

$\mathrm{Na}$ a inauguração desta exposição um dos participantes do grupo contou alguns "causos" que muito divertiram o público presente. Compareceram os dirigentes do MAE e do Centro de Saúde Escola, poucos servidores das duas unidades e muitos moradores da Comunidade. Ela permaneceu aberta durante um dia e meio, pois o espaço da Associação de Moradores é utilizado por diferentes tipos de eventos e à noite por um Curso de Alfabetização de Adultos (Fotos P, Q, R, R1, R2).
7. Visitação à exposição: tanto uma exposição como a outra foram visitadas por uma grande quantidade de pessoas quando de suas inaugurações. $\mathrm{Na}$ exposição Escavando nossa Memória compareceram alguns dos dirigentes e servidores do MAE, parentes e amigos dos participantes e público espontâneo. Nos outros dias em que ficou aberta ao público, entretanto, houve uma visitação mínima.

À exposição Objetos e Lembranças compareceram os dirigentes das duas unidades envolvidas, poucos servidores, quase nenhum familiar 


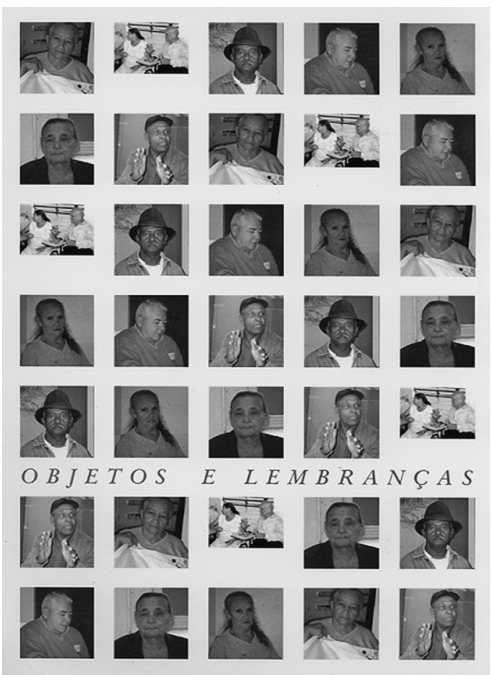

Foto P. Convite/Cartaz da exposição Objetos e Lembranças.
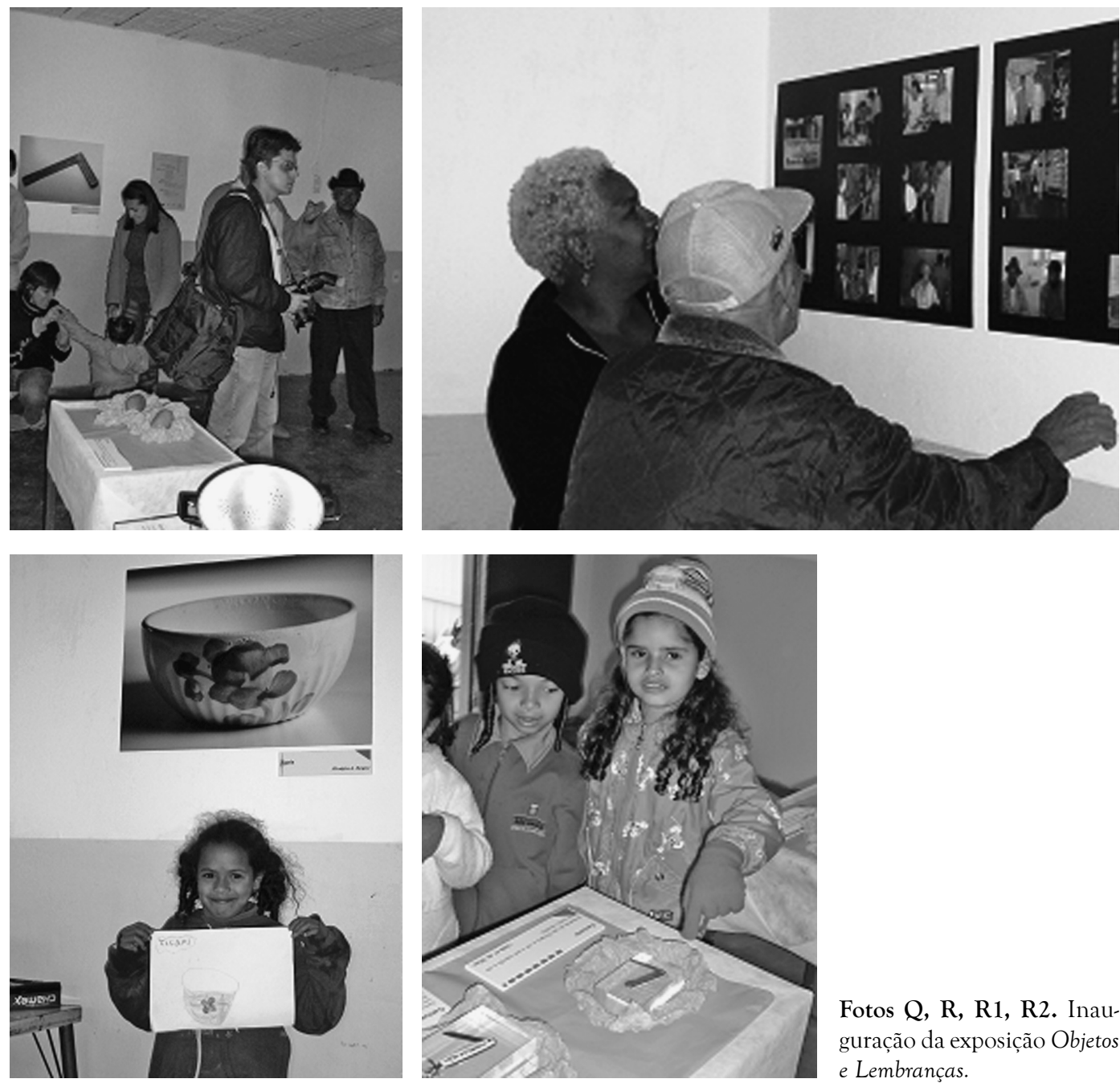

Fotos Q, R, R1, R2. Inauguração da exposição Objetos e Lembranças. 
dos participantes, mas grande quantidade de moradores da Comunidade São Remo. Visitaram esta exposição três escolas que se localizam na Comunidade. ${ }^{17}$ As crianças chegaram com seus professores. Foram recebidas por alguns idosos que fizeram um relato das histórias de seus objetos e pelos coordenadores do Projeto que explicaram o significado da exposição. Finalizaram a visita desenhando alguns dos objetos observados. Com esta socialização das lembranças, os velhos e as crianças buscaram compreensão e sentido para as suas participações (Leite:2006). Foram vários olhares sobre os mesmos objetos o que possibilitou uma maior compreensão sobre a representação dos objetos na vida de cada um. Além disto, houve um reconhecimento mútuo, pois todos habitam o mesmo espaço e têm uma relação com ele, mas não tinham tido até então outro tipo de reconhecimento (Fotos S, T).

A alegria dos participantes de ambos os grupos nestes eventos foi bastante grande e demonstrada em seus semblantes, ora com sorrisos, ora com palavras explicativas e ora com lágrimas nos olhos. Percebeu-se que conseguiram um reconhecimento por seu trabalho de memória a partir de fragmentos de suas histórias de vida relembradas por intermédio de seus objetos agora socializados com o público visitante. Estava estabelecido através desta exposição o sentimento de pertencimento a um grupo nela representado e de identificação com outras pessoas.

8. As exposições são o principal produto final, a síntese das Oficinas da Memória. Elas são a extroversão dos conhecimentos construídos

(17) Visitaram a exposição Objetos e Lembranças e assinaram o livro de presença 222 pessoas, sendo 100 adultos e 122 crianças, mas o número de visitantes deve ter sido maior, pois muitos não registram a presença. a partir da contextualização dos objetos biográficos, a partir da memória que é reconstruída tendo-os como seu suporte. Nestas duas Oficinas, entretanto, houve outros resultados finais, além da exposição de objetos.

Durante cerca de dois meses o grupo da Oficina desenvolveu, após as duas horas regulamentares, exercícios de expressão corpo- 
ral e representação corporal de alguns de seus objetos, como já foi mencionado anteriormente, e um espetáculo que foi apresentado ao público que compareceu à abertura de sua exposição. Foram atividades muito prazerosas que complementaram o trabalho desta Oficina (Fotos U, V).
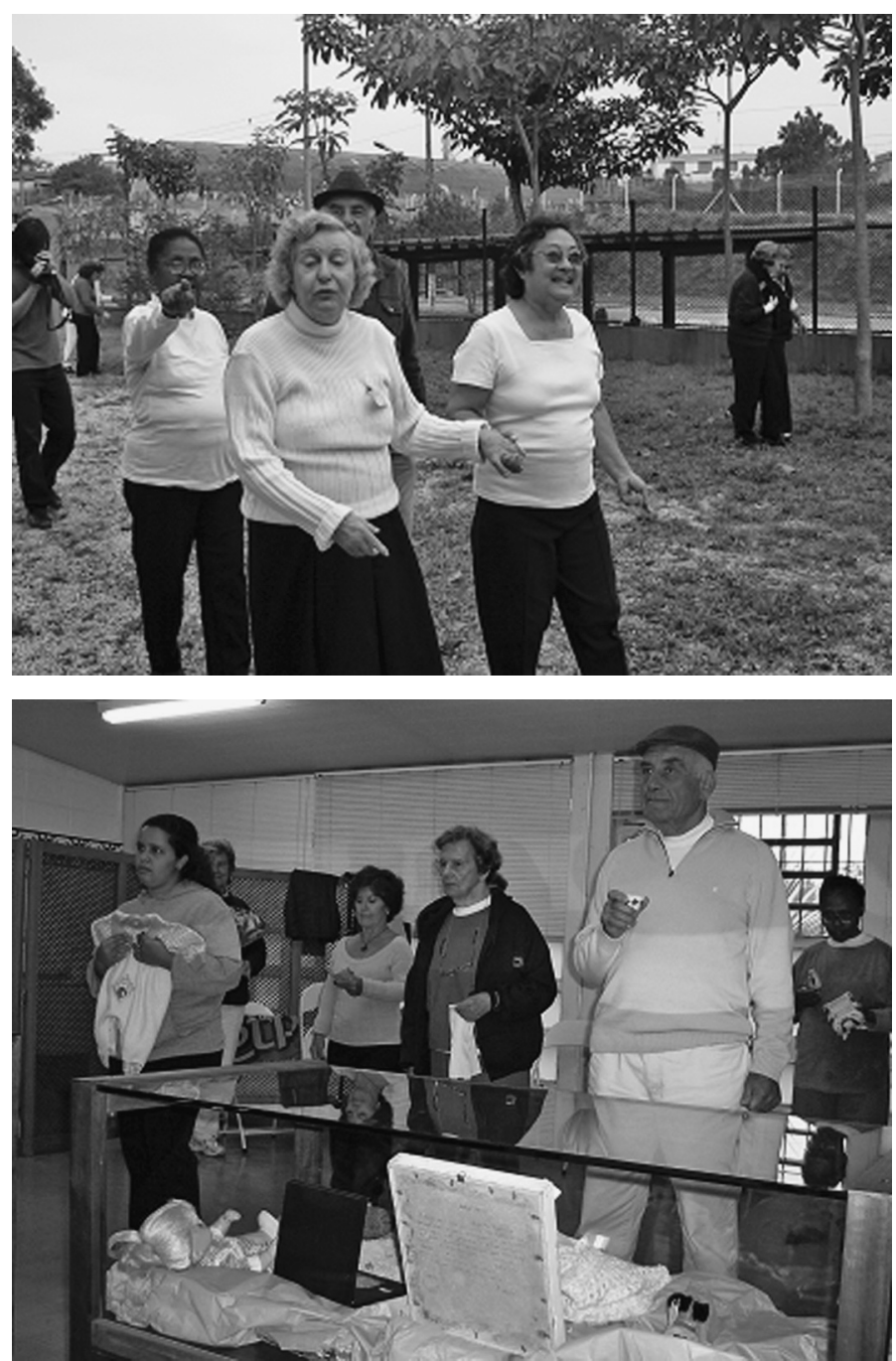

Fotos U, V. Exercícios de expressão corporal do grupo da Oficina da Memória.

O fotógrafo Wagner Souza e Silva propôs a elaboração de uma exposição itinerante, composta pelos painéis fotográficos de objetos dos participantes do grupo da São Remo. Para ele, estas fotos seriam expostas com o objetivo claro de evidenciar a importância de um acervo na construção da memória, mas não pela evidência das fotos milenares, como geralmente acontece em museus, mas sim por meio de objetos do cotidiano contemporâneo. Este tipo de exposição é um mecanismo questionador e de novas formas de percepção e métodos de aproximação com objetos de estudos diversos (Souza e Silva 2007) (Fotos X1 a X7).

A exposição itinerante Objetos e Lembranças ficou quase dois meses no saguão do Centro de Saúde Escola do Butantã. Assinaram o livro de presença aproximadamente 150 pessoas, sendo que algumas deixaram as suas impressões. ${ }^{18}$ Acredita-se que um número muito maior de pessoas a tenha visitado, visto que a exposição estava montada em um espaço estratégico, de passagem, no Centro de Saúde.

A exposição também esteve montada na recepção do MAE/ USP, mas houve pouca visitação. ${ }^{19}$ A Oficina da São Remo terá ainda mais um desmembramento. Está sendo elaborado um livreto. Esta foi a forma encontrada para se retornar aos moradores da Comunidade, para conhecimento e reflexão, alguns conhecimentos recolhidos com o trabalho de memória de alguns de seus habitantes mais velhos.

(18) Alguns comentários de pessoas que visitaram a exposição itinerante quando esteve montada no Centro de Saúde Escola do Butantã:

"Valiosa a mostra da simplicidade de nosso povo. "; "Cada objeto, cada coisa, por mais simples que seja tem sua grandeza."; "Um colírio para os olhos! "; "Eu Roberto

Jefferson apoio esses incentivos à Comunidade."; "Não entendi o objetivo."; "As lembranças trazem histórias, todas são parte de nós."; "Adorei a panela de pressão!"; "Eu achei muito legal, mas chato."; "Muito bom ver a história de nosso bairro."

(19) Esta exposição itinerante será brevemente montada na Faculdade de Medicina da USP. 

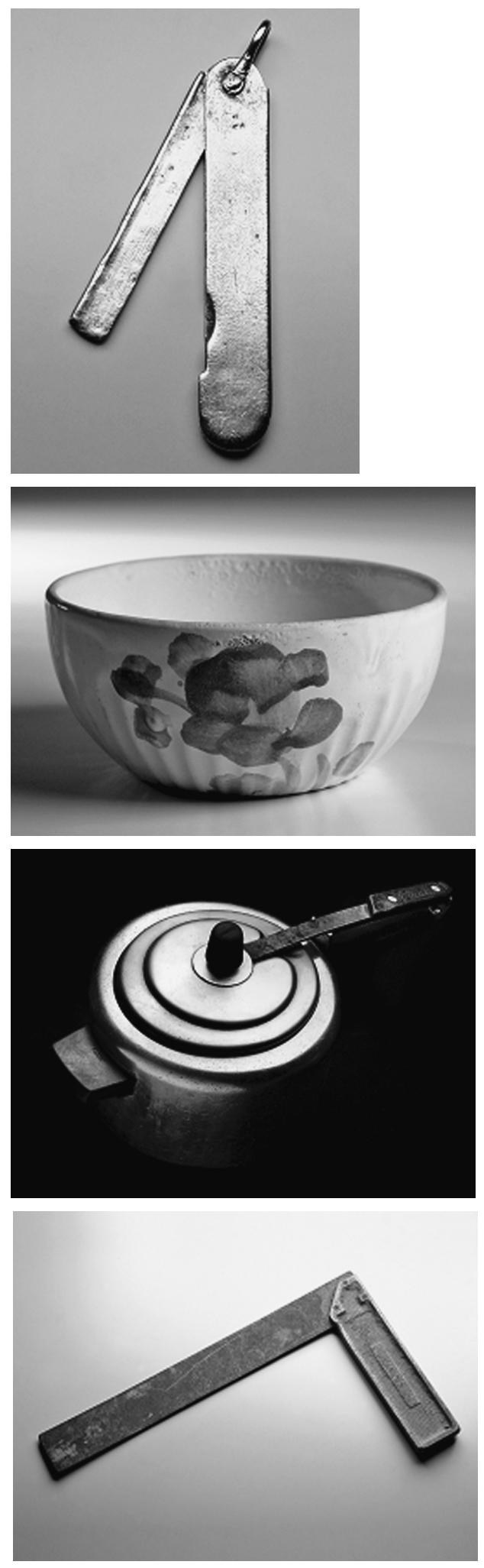
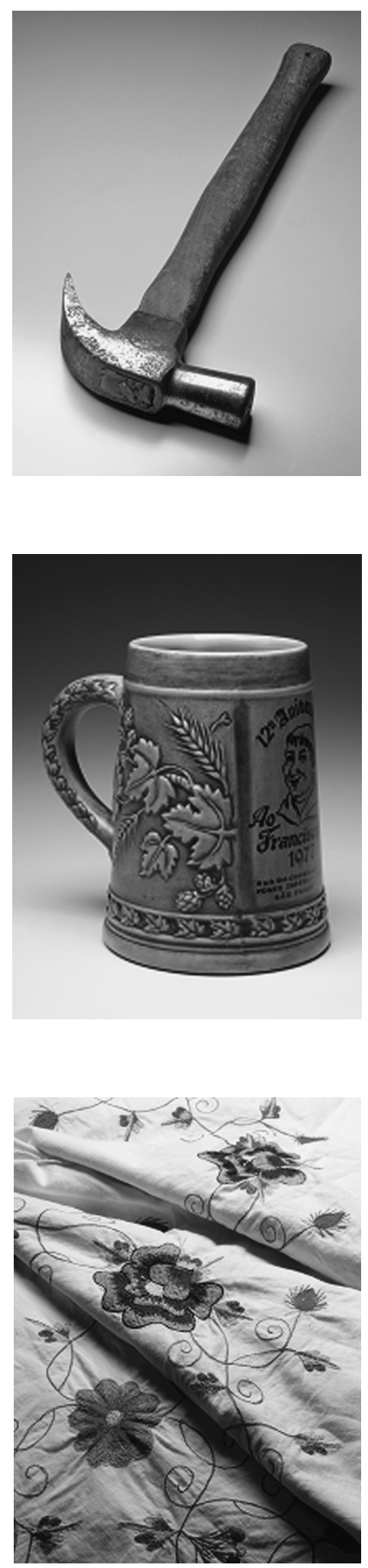

Fotos X1-X7. Painéis fotográficos da exposição itinerante Objetos e Lembranças. 
Este livreto conterá textos explicativos sobre o trabalho realizado, do ponto de vista do fotógrafo, da educadora de saúde, da educadora de museu e das agentes comunitárias de saúde; fotos do processo de trabalho realizado pelo grupo; retratos de seus participantes; fotos dos painéis da exposição itinerante e entrevistas com eles, cujo tema principal é a chegada deles à Comunidade São Remo e as modificações ocorridas em suas histórias de vida e na própria Comunidade.

\section{Considerações finais}

Acreditamos que o museu cumpriu algumas de suas funções, principalmente a de ser um lugar de memória, desenvolver ações educativas em suas práticas sociais como as que foram desenvolvidas nas oficinas aqui apresentadas.
Os trabalhos com públicos especiais dão oportunidade para que se compreenda sua importância dentro da sociedade em que vivem, identifiquem-se como grupo social e que seu processo de construção de conhecimentos seja lúdico e prazeroso.

Os dois grupos de idosos apresentados neste artigo desenvolveram trabalhos de memória com metodologias semelhantes, mas as diferenças geográficas, de escolarização, de saúde física, de valores sociais e culturais, de formas de sobrevivência levaram a reações diversas, tornando os resultados interessantes e ricos em informações sobre as histórias de vida de cada um.

Enfim, este trabalho demonstra que a Cultura Material, seja representada por objetos arqueológicos ou por objetos biográficos, é suporte de informações para se conhecer e compreender os povos e as pessoas que os produziram e utilizaram.

ELAZARI, J.M. Educational action in museums: the Third Age building knowledge from objects in the Museum of Archeology and Etnology - São Paulo University. Revista do Museu de Arqueologia e Etnologia, São Paulo, 19: 337-354, 2009.

Abstract: This article deals with educational actions with elderly people in a public museum. The methodology of this work will be presented. It involves an exploration of objects of the elderly and their life stories. It includes also a parallel between two workshops for elderly people, with similar working methodologies and different results which had as final work the assemblage of an exhibition of contextualized objects.

Keywords: Memory - Education - Museum - Biographical Objects - Elderly.

\section{Referências bibliográficas}

AIDAR, G.

2002 Museus e inclusão social. Ciências $\mathcal{E}$ Letras, Porto Alegre, 31: 53-63.

ALMEIDA, J.R. de; AMORIM, M.A.; BARBOSA, X.

2007 Performance e objeto biográfico: Questões para a História Oral de Vida. Oralidades: Revista de História Oral, 2: 101-109.
ASENSIO, M.; POL, E.

s/d Cuando la mente va al museo: un enfoque cognitivo-receptivo de los estudios de público. Madrid

BOSI, E.

1987 Lembranças de Velhos. Memória e Sociedade. São Paulo: T.A. Queiroz; Editora da Universidade de São Paulo. 
2003 O tempo vivo da Memória. Ensaios de Psicologia Social. São Paulo: Ateliê Editorial.

\section{CHAGAS, M.}

2005 Campo museal: redes e sistemas. Comunicação no I Fórum Nacional de Museus de Santa Catarina.

ELAZARI, J.M.

1997 Relato de uma experiência educativa: Projeto Piloto Patrimônio Cultural e Memória: a Terceira Idade no MAE/USP. São Paulo. Revista do Museu de Arqueologia e Etnologia, 7: 87-97.

GARCIA, V.A.

2005 Um sobrevôo: o conceito de educação não-formal. In: Fernandes, R.S.; Park, M.B. (Orgs.) Educação Não-Formal. Contextos, percursos e sujeitos. Campinas, Unicamp/CMU; Holambra, Editora Setembro: $19-45$.

LEITE, M.I.

2006 Crianças, velhos e museu: memória e descoberta. Cadernos CEDES, 68: 74-85.

MENEZES, U.B. de

2000 Educação e museus: sedução, riscos e ilusões. Ciências $\mathcal{E}$ Letras, Porto Alegre, 27: 91-101.

MORIN, V.

1971 El objeto biográfico. In: Moles, A.A. (Ed.) Los objetos. Buenos Ayres, Tiempo Contemporáneo: 187-199.

NASCIMENTO JR., J. do

2007 Antropologia e museu; revitalizando o diálogo. In: Abreu, R.; Chagas, M.; Santos, M.S. (Orgs.) Museus, Coleções e Patrimônios: Narrativas Polifônicas. Rio de Janeiro, Garamond, MinC/IPHAN/ DEMU: 262-274.

NEVES, E.G.

1995 Os índios antes de Cabral: Arqueologia e História Indígena no Brasil. In: Grupioni, L.D.B.; SILVA, A.L. DA. (Orgs.) A

Temática Indigena na Escola. Novos subsidios para professores de primeiro e segundo graus. Brasília, MEC/MARI/ UNESCO: 171-196.

SOUZA E SILVA, W.

2007 Entre fotografias científicas e a ciência da fotografia. Revista do Museu de Arqueologia e Etnologia, São Paulo, 17: 435-444. 